\title{
Ukrainian educational reforms: brief history review
}

\author{
M. Ia. Kichula, K. B. Oleksii
}

\author{
I. Horbachevsky Ternopil state medical university, Ternopil, Ukraine \\ Corresponding authors.E_mail: kishylamj@tdmu.edu.ua,oleksij@tdmu.edu.ua
}

Paper received 20.10.18; Accepted for publication 25.10.18.

\section{https://doi.org/10.31174/SEND-PP2018-181VI75-07}

\begin{abstract}
The article describes socio-political and pedagogical processes of reforming secondary education in Ukraine. The main transformations in education that have taken place in Ukraine since 1991 up to now are analyzed, not only general tendencies, but also characteristic features of the reform process are revealed in order to predict optimal possibilities of education development in modern conditions on their basis.
\end{abstract}

Keywords: education reform, school education system, Ministry of Education, qualitative education.

The educational sector is a strategically important area of development of society and the state; it must provide such a level of human capital development that will meet the needs and challenges of a post-industrial society and a knowledge economy based on high-tech technologies. It will not be an exaggeration to say that the development of education is a matter of national security.

Ukraine is in the forefront of the trends concerning the transition of humanity to the new phase of civilization development, which is defined not only as an informational society but more often as a society of knowledge.

Of course, there are positive changes in modern national school education, and our country gradually, although not very quickly, moves toward a general modernization. O. Lokshyna (2015) notes that significant achievements of Ukrainian school do not exclude existing of the row of the problems, caused by the number of objective and subjective factors, among which the inconsistency in the implementation of the state educational policy in the field of meaningfulness, the imperfection of the current legislation on the development of state standards, the lack of a thorough calculation of possible positive and negative innovations proposed, insufficient level of integrated scientific support and experimental verification of new subjects / courses, monitoring of successes and failures in the field of content for adoption further decisions [Derzhavna natsionalna prohrama "Osvita" ("Ukraina XXI stolittia"), 2015, p. 27].

To understand the importance of the changes occurring now in Ukrainian education, it is important to pay attention to its preconditions and causes. It is necessary to indicate that in the flow of different scale Soviet reforms in the USSR, part of which was Ukraine, the state system of school education was created. On the eve of the perestroika processes, it has achieved the most significant results, namely: ensuring equal access to education; the growth of the network of secondary schools; an increase in the compulsory duration of general education (from 7 years to 8 years, up to 10 - 11 years of secondary school, from 3 years to 4 years of elementary school); creation of a system of preparation of school students for life, professional activities; the fundamentality of education; realization of the substantiated system of education. At the same times the Soviet school system of education had negative characteristics: state monopoly in the school management, its authoritarian and political character; oversaturation of the content of education and upbringing by communist ideology; the removal of the national component of education and the implementation of its systemic Russification; uniformity of educational institutions, plans, forms and methods of pedagogical process, etc.

At the end of the $80 \mathrm{~s}$ - at the beginning of the $90 \mathrm{~s}$ of the previous century active restructuring of the education under the influence of civil-pedagogical movement was announced from "the above" on the background of the union reform of general and professional school (1984). Thus, its birth occurred from its "bottom", based on the following principles of school education: democratization, deunification, de-ideologization, and national principle. Ministry of National Education of Ukrainian SSR began reconstruction of school education in the context of the Law on languages in the Ukrainian SSR (1989), Declaration on the State Sovereignty (1990) with the purpose of creation of the national system of school education in the following areas: development of national educational legislation; the revival of the Ukrainian school, the restoration of the national component in the content of education. It is necessary to underline that democratic changes, that are the rejection of unification, ideologization, Russification in the field of education; development of a national system of education different from the all-union; implementation of national school reform, became possible after the proclamation of a sovereign Ukrainian state (1991), self-dissolution of the CPSU, the collapse of the USSR. The regulatory framework of the development of school education of Ukraine (Conception of the general national school of Ukraine, 1990; the Law of Ukraine "On education", 1991), was being actively developed at that time.

Transformations in education influence the society much. The specialist had repeatedly emphasized that, firstly, it is necessary to initiate nationwide discussion of the purpose of reformation, the content of the reforms and their consequence; widely discuss these questions of scientific and scientific and practical conferences, meetings of scientists councils, parental meetings, in mass media, etc. [Bakhanov K., 2006, p. 7]. Thus, at the beginning of the 1996 Scientific and Coordination Council was found. The result of its work is the development of the conception of State standard of general secondary education, preparation of which began yet in 1994. In addition, temporary creative collectives were formed for development standards in each area. 
The next step of reformation was passing of the branch normative act of direct action - the Law "On general secondary education" by the Verkhovna Rada of Ukraine in May 1999, on the basis of which the Resolution of the Cabinet of Ministers "On the transition of general educational institutions to the new content, structure and 12-year education" of July 16, 2000, was published. In 2001, the Board of the Ministry of Education approved the Conception of General Secondary Education (12-year school).

The new system of assessment of the knowledge of students under the 12-grade scale and semester control was introduced in the 2000-2001 educational year. The changes in the assessment criteria allowed to overcome such a phenomenon as a secondary issue.

In 2001, the All-Ukrainian Congress of Education Workers took place, which was subsequently approved by the President of Ukraine, the National Doctrine of Education Development, a strategic plan, created as a source for a group of legislative acts, as a guideline for fundamental changes. Modernization of the area to the needs of the 21st century is defined as the main goal of it.

Approval of the State standard of the base and full secondary education, according to the law and the resolution on the transition to the 12-year term of education, became an important event in 2004. Specialists note positive sides of standardization, but, at the same time, they emphasize that its initial stage certifies certain arrangement of State standards with other conceptual educational documents, their insufficient consideration of modern approaches, including competence approach and the need in further improvement [Bakhanov K., 2006, p. $6]$.

Following the experience of the nearest neighbors, Ukraine has recently begun to consider the state and methods of education improvement on different levels: on parliamentary sessions in Verkhovna Rada of Ukraine (December 2005), on Collegium of the Ministry of Education and Science of Ukraine ("Quality education is the key to self-realization of the individual", Kyiv, 2007), in the results of social polls, expert assessments of national and foreign specialists ("Strategy of reformation of education in Ukraine. Recommendations on educational policy", Kyiv, 2005), materials of the National Academy of Educational Sciences ("Problems of the quality of education: Theoretical and practical aspects, Kyiv, 2007) etc.

Thus, education in Ukraine undergoes reformation with use of general European experience of adaptation of youth to life under competitive conditions of modern society. However, these reforms are not without contradictions. Thus, in 2010 the Verkhovna Rada of Ukraine introduced amendments to the Law "On general secondary education", which established the 11-year term of education for obtaining a general secondary education, allowed distance learning, opening of special classes for teaching students with special needs. To preserve the network of village schools, the norm was introduced to the Law "On general secondary education". It came into force at the beginning of 2011 and related to the fullness of the classes with at least three students (comparatively to the previous norm - at least five students in the class).

Nevertheless, nowadays there is no clear system of improvement of the quality of education in Ukraine, although debates on these grounds last for over 20 years. One of the generally recognized achievements of our state is the introduction of an external independent evaluation (testing) (EIT) in 2008. Analysis of the level of knowledge of students on the EIT indicates the possibilities of the perspective of the improvement of the quality of education. Another achievement of Ukraine is founding of the Institute of Educational Analytics of the Ministry of Education and Science of Ukraine in 2015, the priority task of which is organization and coordination of the studies and developments on the issues of studying the qualitative and quantitative state of the education system.

Conclusions. Consequently, in recent decades, significant international experience of positive reformation of education has been introduced in Ukraine, in particular: the transition to a new system of evaluation, the introduction of a system for the search, development and support of creative students, and the introduction of pedagogical innovations.

\section{REFERENCES}

1. Derzhavna natsionalna prohrama "Osvita" ("Ukraina XXI stolittia") [State National Program "Education" ("Ukraine XXI Century")] Available at : http:// z a k o n . r a d a . g o v . u a / c g i - b i n / 1 a w s / main.cgi?page $=3 \& n r e g=896-93-$ $\%$ EF (accsseded at 9 May 2018).

2. Bakhanov K. (2006) Derzhavnyi standart zahalnoi serednoi osvity: shliakhy vdoskonalennia [State standard of secondary education: ways of improvement]. Ridna shkola, no 6, pp.67.

\footnotetext{
3. Zakon Ukrainy «Pro osvitu» // Vidomosti Verkhovnoi Rady Ukrainy. - 1991. - No34. - St. 454.

4. Lokshyna O. Evoliutsiia reform shkilnoi osvity v krainakh Yevropeiskoho Soiuzu / O. Lokshyna // Shliakh osvity. 2006. - No4. - S. 19
} 